(6)

OPEN ACCESS

\title{
Adult scurvy associated with psychiatric disorders and breast feeding
}

\author{
Stefania Urueña-Palacio, ${ }^{1,2}$ Bruno L. Ferreyro, ${ }^{1,2}$ Lucas G. Fernández-Otero, 1,2 \\ Pablo D. Calo ${ }^{3,4}$
}

'Department of Internal Medicine, Hospital Italiano de Buenos Aires, Autonomous City of Buenos Aires, Argentina ${ }^{2}$ Department of Internal Medicine, Hospital Italiano de San Justo Agustín Rocca, San Justo, Buenos Aires, Argentina ${ }^{3}$ Department of Intensive Care, Hospital Italiano de Buenos Aires, Autonomous City of Buenos Aires, Argentina ${ }^{4}$ Department of Intensive Care, Hospital Italiano de San Justo Agustín Rocca, San Justo, Buenos Aires, Argentina

\section{Correspondence to}

Dr Stefania Urueña-Palacio, stefania.uruena@

hospitalitaliano.org.ar

Accepted 8 February 2018

\section{SUMMARY}

Scurvy is a nutritional disease caused by ascorbic acid deficiency and is potentially fatal. It was originally described in the 18th century by James Lind and associated with long sea voyages and insufficient citrus consumption. Its prevalence has declined markedly over the years but has still been described sporadically in certain countries. A 22-year-old woman with an anxiety disorder and anorexia nervosa, recent pregnancy and ongoing breast feeding, presented with a 10day history of spontaneous haematomas in the lower limbs, gingivorrhagia and fatigue. The examination was remarkable for signs of minor bleeding without haemodynamic compromise, gonalgia and pale skin. Work-up studies revealed the presence of anaemia. Direct anamnesis identified a diet based solely of tea and carbohydrates due to distorted body image. With the working diagnosis of scurvy, nutritional support and oral vitamin C supplementation was initiated. Her symptoms and anaemia resolved in 30 days and the diagnosis was confirmed biochemically.

\section{BACKGROUND}

The ancient Egyptians described symptoms of scurvy as early as 1500 BC. In contemporary history, epidemics were described in the Renaissance era and during the 18th century by James Lind on British sailors at sea in 1746. Similar epidemics were also described during the Great Irish Famine, California Gold Rush and army life in the American Civil War. ${ }^{1}$

Vitamin C, an enzyme cofactor and strong reducing agent, is crucial in several biochemical pathways such as collagen synthesis and antioxidant reactions. Its deficiency is frequently associated with folate and iron deficiency for sharing dietary sources. $^{2-4}$ Humans require exogenous vitamin C for the formation of collagen and to prevent tissue breakdown.

The presence of collagen synthesis disruption and consequent increased acute-phase reactant activity lead to the clinical syndrome of scurvy. This includes asthenia, arthralgia, myalgia, gingival hypertrophy, spontaneous bleeding (ecchymosis, petechiae and mucosal bleeding) and subsequent anaemia. In severe cases, patients can develop jaundice, fever and visceral bleeding with an increased mortality risk. ${ }^{67}$ Mood disturbances are also frequent. ${ }^{89}$

A diagnosis of scurvy is uncommon at present but still sporadically described. In adults, it can be associated with malabsorption syndromes, malnutrition, pregnancy/breast feeding, alcoholism or drug abuse, smoking and mental health conditions. It is an underestimated illness but with a favourable prognosis if early diagnosed. Treatment with vitamin $C$ supplementation leads to an improvement of symptoms in 2 to 4 weeks.

\section{Check for updates}

To cite: Urueña-Palacio $S$, Ferreyro BL.,

Fernández-Otero LG., et al. BMJ Case Rep Published Online First: [please include Day Month Year]. doi:10.1136/bcr-2017-

223686

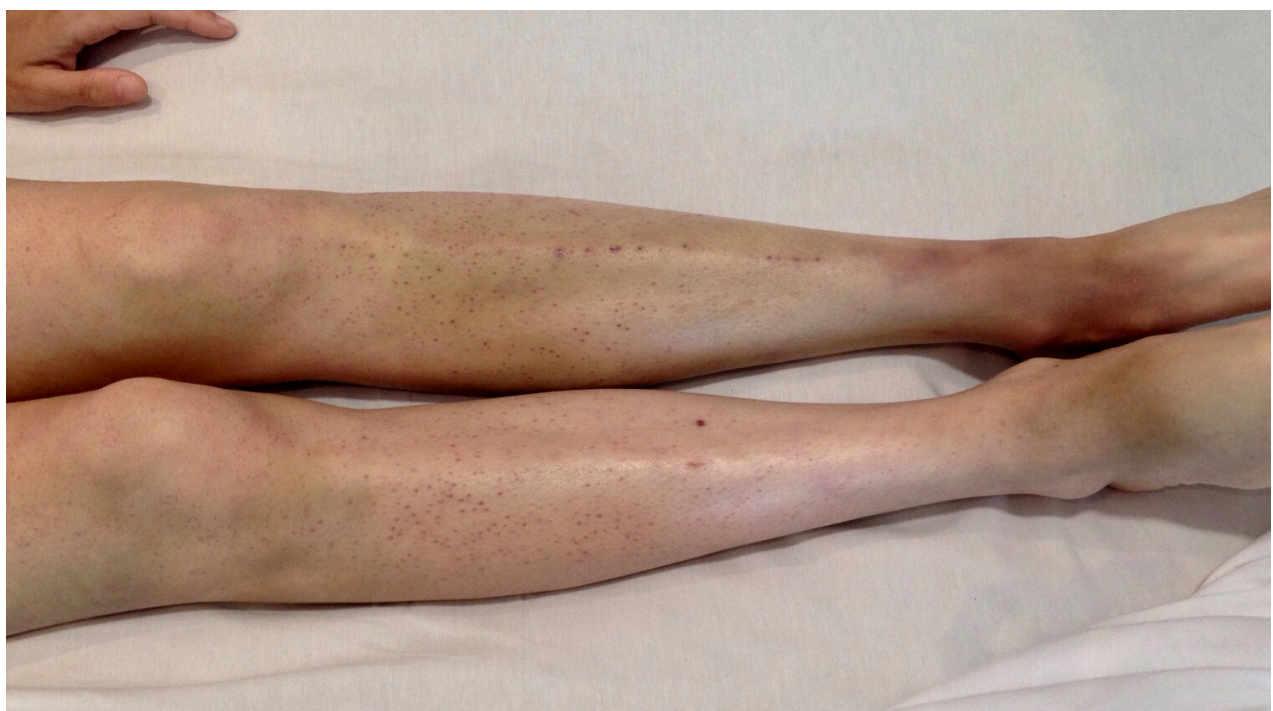

Figure 1 Petechiae and ecchymosis in anterior region of the legs. 


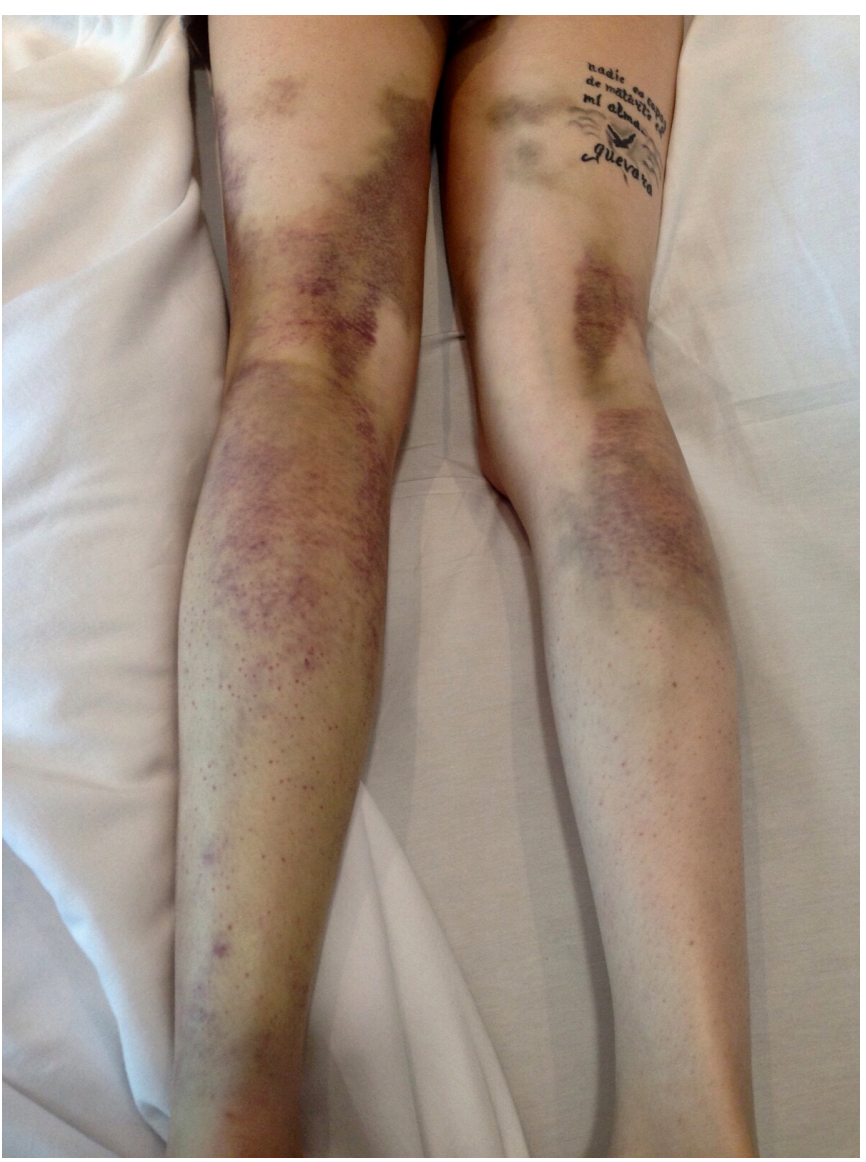

Figure 2 Extensive ecchymosis and petechiae in posterior regions of the lower limbs.

\section{CASE PRESENTATION}

A 22-year-old woman with a history of anxiety, anorexia nervosa and recent pregnancy with ongoing breast feeding presented to the emergency department with a 10-day history of asthenia, left-knee pain and a spontaneous petechial rash of the lower limbs. She also expressed a decreased vegetable and citrus intake during the previous 3 months due to dyspepsia. Other remarkable complaints were gingivorrhagia and hypermenorrhoea. She denied previous abortions, drug abuse or a family history of bleeding disorders.

Physical examination revealed a haemodynamically stable patient with the presence of pale skin mucosa, oedema of the left knee, petechiae and ecchymosis in anterior and posterior

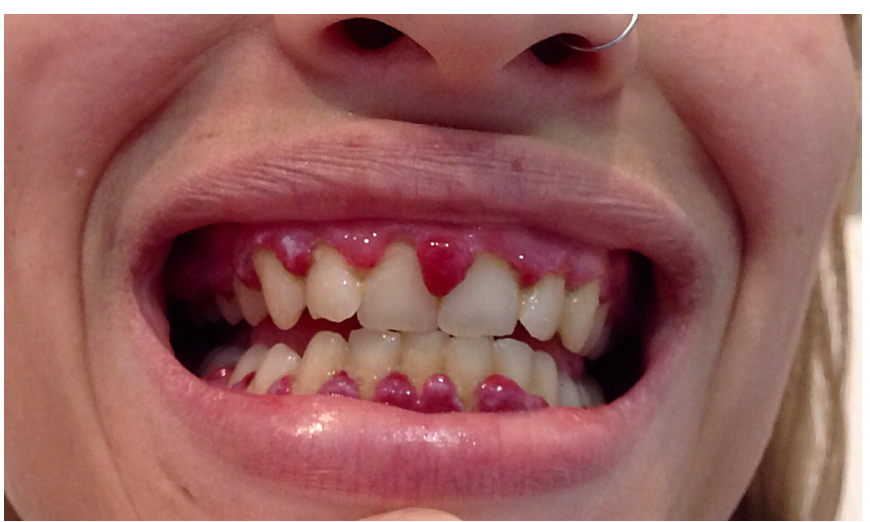

Figure 3 Severe gingival hypertrophy. regions of the lower limbs (figures 1 and 2) and significant gingival hypertrophy (figure 3). Her body mass index of $14 \mathrm{~kg} /$ $\mathrm{m}^{2}$ supported the evidence of severe underweight. The examination did not provide other findings attributable to bleeding, visceromegaly or lymphadenopathy.

\section{INVESTIGATIONS}

Complementary studies revealed the presence of acute normochromic normocytic anaemia (haemoglobin level $8 \mathrm{mg} / \mathrm{dL}$ ), with a 3-point decrease compared with a test done 10 days before. Platelets, prothrombin time, partial thromboplastin time, fibrinogen, renal and liver function tests were in the normal range. A chest X-ray, abdominal ultrasound and ECG were also unremarkable.

The patient was admitted to hospital in an intermediate care unit for close monitoring and investigation of a potential underlying coagulation abnormality. Specific tests such as coagulation factors, complement levels, D-dimer, lupus anticoagulant and thromboelastography did not show any abnormalities. She also presented ferritin values at the lower limit and $\mathrm{B}_{12}$ vitamin deficiencies, but coeliac and thyroid diseases were discarded. A leftknee haemarthrosis was confirmed by ultrasound.

\section{TREATMENT}

During hospital admission, conservative management of knee haemarthrosis and other bleeding sources was decided on. Considering a presumptive diagnosis of scurvy, the nutritional and psychiatric teams were involved in the care of this patient. After drawing a blood sample that was derived for ascorbic acid levels testing, empirical treatment with vitamin C $(1000 \mathrm{mg} /$ day $)$ and iron was initiated. The patient remained clinically stable, with no worsening bleeding and stable haemoglobin. For this reason, hospital discharge was decided with close follow-up.

\section{OUTCOME AND FOLLOW-UP}

The patient attended outpatient clinic follow-up at days 7, 14 and 30. By that time, the signs of spontaneous bleeding had resolved. The haemoglobin levels increased to normal and the patient showed a progressive increase in weight $(4.2 \mathrm{~kg})$. The dosage of plasmatic vitamin C levels (method high-performance liquid chromatography) showed values at the lower limit of normality $(0.26 \mathrm{mg} / \mathrm{dL})$, which added to the clinical criteria and a rapid response to specific treatment, confirmed the diagnosis of scurvy.

\section{DISCUSSION}

The features of scurvy in this young patient included fatigue, pain and the classic signs of spontaneous minor bleeding and anaemia without haemolysis or shock. The clinical suspicion of this disease should be raised in vulnerable groups for avitaminosis, such as patients with several malnutrition disorders. Therefore, it should still be considered while assessing patients with spontaneous bleeding in the presence of alcoholism, malabsorption syndromes, pregnancy and breast feeding. Other situations that should be taken into account are emerging and becoming established such as conditions of extreme poverty, war and periods of massive immigration (ie, refugees).

A literature review since 1957 revealed the presence of 410 cases reported worldwide. Of these, half occurred in adults. It is important to note that these reports come from both high income and low-middle income countries, highlighting the fact that this disease does not distinguish social class and seems to be related to the scourge of addictions, psychiatric disorders, as well as the growing trend in choosing fast food diets based on carbohydrates. ${ }^{10} 11$ 
The present case is the first to report the presence of this disease in the combination of increased physiological nutritional requirements, low socioeconomic status and distortion of body image due to eating-psychiatric disorders.

Scurvy can be a potentially fatal disease. Previous literature reported cases presenting with severe haemodynamic compromise and a systemic inflammatory response. The differential diagnosis is wide and includes systemic diseases such as haematological and rheumatological, and localised disorders such as periodontal diseases.

Once a diagnosis has been suspected, the coexistence of other biochemical deficits should be considered. These include zinc, ${ }^{12}$ iron and vitamin B. Moreover, the presence of conditions that may worsen or affect adherence to treatment such as gastro-oesophageal reflux and stomatitis should also be considered. In the present case, since the diagnosis was probable, we decided not to perform additional complementary tests.

In summary, we present a case of an adult in Argentina with unique characteristics, which leads us to reflect on the changes in human behaviour and dietary habits especially over the last 10 years. It is important to emphasize that an incorrect diagnosis can lead to increased morbidity and the misuse of resources in global public health.

\section{Learning points}

- Adult scurvy does not distinguish social class and seems to be related to dietary habits or pathological behaviour.

- Adult scurvy should be maintained in the differential diagnosis of spontaneous bleeding, particularly in patients with nutritional disorders.

- The diagnosis and treatment can be simple, non-invasive with total and persistent recovery, being effective in the short term.

- A multidisciplinary teamwork plays a valuable role and the prognosis is favourable if adequately treated.

Acknowledgements We thank the patient of this case and the Internal Medicine Residency of the Hospital Italiano de Buenos Aires.
Contributors SUP, BLF, LGFO and PDC contributed to the conception, design of the work, analysis and interpretation of the case. All the authors contributed equally to revising it critically for important intellectual content and the final approval of the version published.

Funding This research received no specific grant from any funding agency in the public, commercial or not-for-profit sectors.

Competing interests None declared.

\section{Patient consent Obtained}

Provenance and peer review Not commissioned; externally peer reviewed.

Open Access This is an Open Access article distributed in accordance with the Creative Commons Attribution Non Commercial (CC BY-NC 4.0) license, which permits others to distribute, remix, adapt, build upon this work non-commercially, and license their derivative works on different terms, provided the original work is properly cited and the use is non-commercial. See: http://creativecommons.org/ licenses/by-nc/4.0/

(C) BMJ Publishing Group Ltd (unless otherwise stated in the text of the article) 2018. All rights reserved. No commercial use is permitted unless otherwise expressly granted.

\section{REFERENCES}

1 Carpenter KJ. The history of scurvy and vitamin Cambridge. New York, NY: University Press, 1986:158-72.

2 McLean E, Cogswell M, Egli I, et al. Worldwide prevalence of anaemia, WHO Vitamin and Mineral Nutrition Information System, 1993-2005. Public Health Nutr 2009;12:444-54.

3 Ministerio de Salud de la Nación. Nutrición y Embarazo. Recomendaciones en Nutrición para los equipos de salud: Dirección Nacional de Maternidad e Infancia. Buenos Aires: Ministerio de Salud, 2012.

4 Elisa ZM, Alicia R, Paula P, et al. Situación alimentaria nutricional de las embarazadas y madres en periodo de lactancia de Argentina. 2016;34:33-40.

5 Levine M. New concepts in the biology and biochemistry of ascorbic acid. N Eng/ J Med 1986;314:892-902.

6 McGraw-Hill. Harrison's principles of internal medicine. 16th edn. New York, NY: McGraw-Hill, 2004:406-7.

7 Hirschmann JV, Raugi GJ. Adult scurvy. J Am Acad Dermatol 1999:41:895-910.

8 Dey N, Nazif TM, Sharpe B, et al. Stranded in San Francisco. Lancet 2008;372:1008.

9 Dube M. Scurvy in a man with schizophrenia. Can Med Assoc J 2011:183:E760.

10 Al-Dabagh A, Milliron BJ, Strowd L, et al. A disease of the present: scurvy in "wellnourished" patients. J Am Acad Dermatol 2013;69:e246-7.

11 Wang AH, Still C. Old world meets modern: a case report of scurvy. Nutr Clin Pract 2007:22:445-8.

12 Velandia B, Centor RM, McConnell V, et al. Scurvy is still present in developed countries. J Gen Intern Med 2008;23:1281-4.

Copyright 2018 BMJ Publishing Group. All rights reserved. For permission to reuse any of this content visit

http://group.bmj.com/group/rights-licensing/permissions.

BMJ Case Report Fellows may re-use this article for personal use and teaching without any further permission.

Become a Fellow of BMJ Case Reports today and you can:

- Submit as many cases as you like

- Enjoy fast sympathetic peer review and rapid publication of accepted articles

- Access all the published articles

- Re-use any of the published material for personal use and teaching without further permission

For information on Institutional Fellowships contact consortiasales@bmjgroup.com

Visit casereports.bmj.com for more articles like this and to become a Fellow 